\title{
Developing of Key Competencies by Means of Augmented Reality at CLIL Lessons
}

\author{
Olexandr V. Merzlykin ${ }^{10000-0003-2601-5713]}$, Iryna Yu. Topolova ${ }^{1}$ \\ and Vitaliy V. Tron ${ }^{20000-0002-6149-5794] ~}$ \\ ${ }^{1}$ Kryvyi Rih Educational Complex No 129 "Gymnasium-Lyceum of Academic Approach", \\ 39, Penzenska St., Kryvyi Rih, 50048, Ukraine \\ \{merzlykin, topolova\}@physics.ccjournals.eu \\ ${ }^{2}$ State Institution of Higher Education "Kryvyi Rih National University", \\ 11, Vitali Matusevich St., Kryvyi Rih, 50027, Ukraine \\ vtron@ukr. net
}

\begin{abstract}
Using of new learning and IC technologies is necessary for effective learning of modern students. Their specific educational needs are: using of mobile ICTs, collaboration, challenging tasks and entertainment. Appropriate learning environment should be created to satisfy all these demands. It ought to deal with cloud-based technologies (for 24/7 access, individual and group work according to a personal schedule), augmented reality (for creating of firm links between real and virtual objects), content and language integrated learning (for immersion in an additional language and creation challenging groups and personal tasks in language and non-language subjects). Using these technologies in complex provides social and ICT mobility and creates positive conditions for developing 9 of 10 key competencies. The paper deals with the features, problems and benefits of technologies' implementation in secondary schools. To sum up, in spite of all difficulties, this environment helps students to get some practical experience in using foreign languages and understanding abstract nature concepts; to develop language and research competencies and to remain motivated (and self-motivated) in learning Science and English.
\end{abstract}

Keywords: Augmented Reality, Science Learning, Key Competencies, Generation Z, Content and Language Integrated Learning (CLIL).

\section{$1 \quad$ Introduction}

Current secondary school students are members of so-called "Generation Z" cohort. This term is based on Strauss-Howe generational theory. It is often criticized as simplified and pop-sociological. However, we can use the terms as markers for social statistics study. Most of "Zeds" have been using ICT since a young age. Technologies and social network are the essential parts of their world. Consequently, using ICT in education is not an option but a necessity. The most helpful educational technologies for "Zeds" are smartboards, digital textbooks, websites, online videos and game-based learning systems. "Zeds" also prefer studying with friends. Their favorite educational 
activities are class discussions and working through problems or concepts [1, pp. 6-8]. That is why we have to create learning environment which contains ICT, supports online learning and provides wide opportunities for students' collaboration and effective education. A possible solution lies in using cloud-based technologies (for example, based on Google Classroom - G Suit learning management system [13]).

\section{ICT Component of Learning Environment}

\subsection{Traditional Cloud-based ICTs}

The cloud-based ICTs can be widely used in science learning at secondary schools. We use project management software, virtual labs, virtual simulators, electronic organizers, content analysis tools, electronic lab notebooks, media editors, programming languages and libraries, physical process modeling software, presentation programs; computer algebra systems; statistical packages, spreadsheets and word processors for various purposes [10]. This software is used both in a classroom and at home. Thereby, students operate with virtual objects as well as with real ones. Unfortunately, the links between these objects are not obvious in classic systems and students often do not match real objects with their virtual representations. This problem can be solved with augmented reality (AR) using.

\subsection{Using Augmented Reality in Science Learning}

The technology of augmented reality attracted the attention of a wide audience in the summer of 2016, when Niantic and Nintendo launched Pokémon Go computer game. However, the history of the augmented reality successful application has at least 25 years [16]. The ideas about using this technology in education were expressed by Ivan E. Sutherland [17], who was the developer of the first systems of virtual and augmented reality. He wrote about the country of miracles, which is opened to the users of these systems, and he focused on their benefits while assimilating the abstract concepts of modern science (in particular, the fields and interactions of elementary particles) [18, p. 507].

That is, the ideas of augmented reality application in education have appeared even before the first augmented reality system was created. In addition to visualizing abstract concepts and objects, that cannot be perceived directly, the importance of augmented reality for training specialists, who work with unique, dangerous or very expensive equipment (astronauts, doctors, pilots, welders, etc.), is obvious. The only factor, that restrained the development of augmented reality learning environments for decades, was the advancement of computer technologies. Nowadays this issue is not so acute due to the proliferation of mobile devices [14, p. 95].

Jean-Marc Cieutat, Olivier Hugues, and Nehla Ghouaiel define AR as the combination of physical spaces with digital spaces in semantically linked contexts for which the objects of associations lie in the real world [3, p. 32]. According to Gartner hype cycle analysis (see Fig. 1) AR is a mature technology and it will reach the plateau of productivity in 5-10 years [19]. Thus, in the near future the number (and quality) of augmented 
reality software and hardware is supposed to be increased. Augmented reality is implemented in Ukraine slower than in some countries [11, p. 32], but its popularity in our country is currently growing (according to Gartner reports for 2010-2011). However, sustainable development of appropriate means abroad is likely to lead to accelerated, compared to Fig. 1, speed of augmented reality by hype cycle in Ukraine. Consequently, the forecast of augmented reality reaching the plateau of productivity in Ukraine within the next 10-15 years seems to be real.

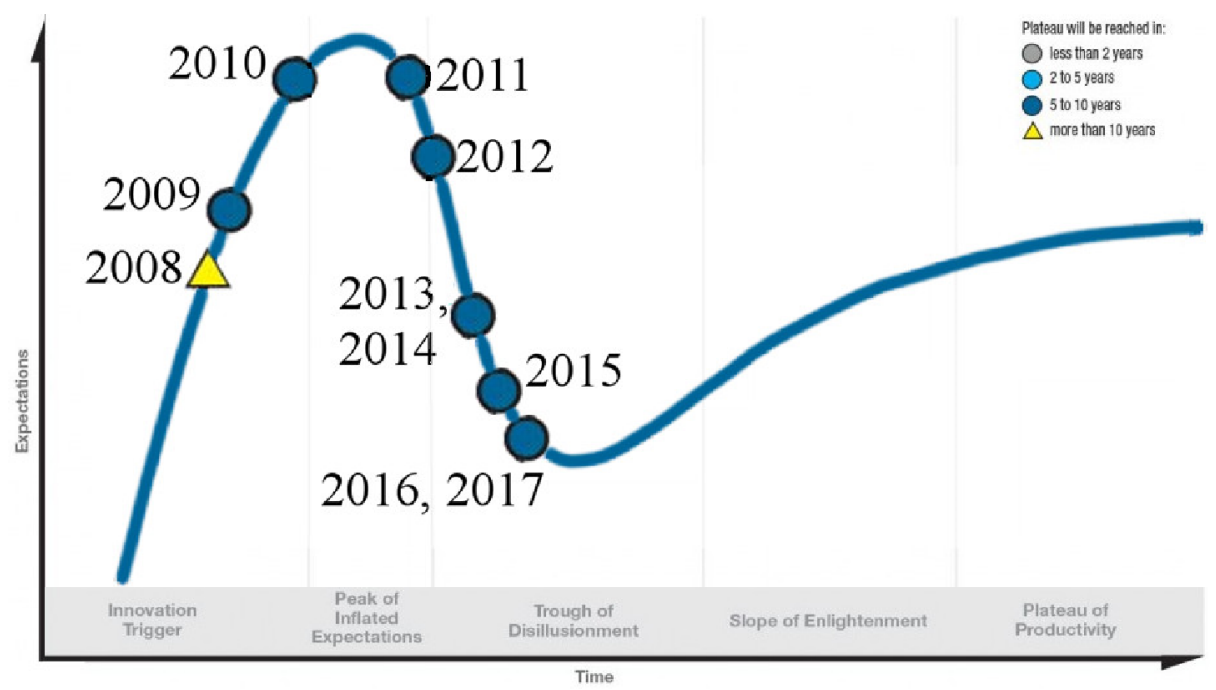

Fig. 1. The trajectory of AR at the Gartner hype cycle since its first appearance in Gartner reports till now

Undoubtedly, the increasing number of augmented reality applications for mobile devices contributes to this process. The use of this software in education provides an opportunity to accommodate the vast majority of subjects of the educational process both in high and secondary schools: our experience shows that the proportion of the students who are able to use mobile Internet devices in the classroom is not less than $90 \%$. In addition, augmented reality applications for mobile devices can naturally be a part of the mobile learning environment [20, p. 46], which benefits are thoroughly compared with classical ones in [8].

Stanley Pierre-Louis in his testimony before the U. S. Senate Committee on Commerce, Science \& Transportation of United States Senate said that "the applications of these technologies [AR and mixed reality] to education are endless" [6, p. 7] and pointed some of these applications. In this paper we will review some possibilities of using AR in learning Science subjects at secondary schools.

Mark Billinghurst and Andreas Dünser [2] note that augmented reality is able to expand traditional learning models. The authors emphasize that augmented reality facilitates the understanding of complex phenomena, provides unique visual and interactive experience, that combines real and virtual data, and helps to interact with digital content. 
What is more, the use of augmented reality promotes new forms of collaboration, educational cooperation and motivates students to work actively both in the classroom and remotely. According to the authors [2], augmented reality allows creating a unique educational environment, but at the same time they note that possibilities of augmented reality and its application should be studied in more detail.

Phil Diegmann, Manuel Schmidt-Kraepelin, Sven van den Eynden, and Dirk Basten [5] have studied the experience of using augmented reality in education. They have analyzed and systematized the use of augmented reality in 25 publications according to directions of its usage and training benefits (table 1). Each cell of the table contains the relative number of publications which describe the benefits of using augmented reality in this area.

Table 1. Benefits of using augmented reality in education

\begin{tabular}{|l|c|c|c|c|}
\hline & Directions & & & \\
Benefits & & & & \\
& & & \\
& & & \\
\hline Motivation & $28 \%$ & $16 \%$ & $4 \%$ & $4 \%$ \\
\hline Attention and Concentration & $16 \%$ & $0 \%$ & $0 \%$ & $0 \%$ \\
\hline Satisfaction of Learning Needs & $4 \%$ & $8 \%$ & $4 \%$ & $4 \%$ \\
\hline Student-centered Learning & $8 \%$ & $0 \%$ & $0 \%$ & $0 \%$ \\
\hline Collaborative Learning & $4 \%$ & $8 \%$ & $0 \%$ & $0 \%$ \\
\hline Details in Data Presentation & $0 \%$ & $0 \%$ & $4 \%$ & $0 \%$ \\
\hline Accessibility Information & $0 \%$ & $0 \%$ & $4 \%$ & $4 \%$ \\
\hline Interactivity & $4 \%$ & $0 \%$ & $0 \%$ & $0 \%$ \\
\hline Learning Curve & $24 \%$ & $16 \%$ & $24 \%$ & $4 \%$ \\
\hline Creativity in Learning & $8 \%$ & $0 \%$ & $0 \%$ & $0 \%$ \\
\hline Spatial Abilities & $0 \%$ & $8 \%$ & $4 \%$ & $0 \%$ \\
\hline Memory & $4 \%$ & $0 \%$ & $8 \%$ & $0 \%$ \\
\hline Reduced costs & $0 \%$ & $4 \%$ & $4 \%$ & $0 \%$ \\
\hline
\end{tabular}

Thus, using augmented reality:

- facilitates the understanding of complex phenomena with the help of unique visual and interactive experience, that combines real and virtual data;

- promotes the effective demonstration of abstract concepts;

- motivates students to learn, making educational process more effective and interesting;

- supports the development of new forms of cooperation and sharing of educational experience;

- involves students in active learning in the classroom as well as remotely. 
To sum up, the main benefits of using AR are linked to opportunities for studying objects and phenomena, which are inaccessible for direct cognition, but can be observed by the meanings of AR. It can be very useful in learning abstract Maths and Science concepts. Moreover, AR shows the links between real and virtual objects. For example, students can see that constant chaotic moving of molecules is not a "thing-in-itself", but the nature of the gas. Moreover, AR can be a good example of developing technology by itself and show accelerating progress in the modern world. At schools AR can form some "digital" habits, which can be useful in future life. Using AR in a classroom makes it possible to learn in personal-oriented environment. It helps students to provide their own learning (and self-learning) styles.

According to The State Standard of the Basic and Complete Secondary Education key competencies are [7]:

- native language competency;

- foreign language competency;

- mathematical competency;

- competencies in science;

- digital competency;

- lifelong learning;

- social and civic competencies;

- sense of initiative and entrepreneurship;

- cultural awareness;

- ecological competencies and health care.

Every competency consists of four components: cognitive (related knowledge and intellection), praxeological (needed skills and experience), axiological (personal values and motivation to develop competency), social and behavioral (personal habits and abilities in communication and cooperation in providing main activity of the competency) $[12$, p. 58]. The benefits of using AR in secondary education (in regard to key competencies) are given in the Table 2. If a competency is not presented in the table, it means that it is hard to distinguish the influence of AR on its forming.

Table 2. Advantages of using AR at science lessons (in regard to key competencies)

\begin{tabular}{|c|c|c|c|c|}
\hline \multirow[b]{2}{*}{ Competency } & \multicolumn{4}{|c|}{ Component of Competency } \\
\hline & Cognitive & $\begin{array}{l}\text { Skills and } \\
\text { Experience }\end{array}$ & Values & $\begin{array}{l}\text { Social and } \\
\text { Behavioral }\end{array}$ \\
\hline $\begin{array}{l}\text { Mathematical } \\
\text { Competency }\end{array}$ & \begin{tabular}{|lr} 
supporting of ab- \\
stract & mathemati- \\
cal r & concepts \\
learning &
\end{tabular} & $\begin{array}{l}\text { scaffolding of } \\
\text { basic math skills } \\
\text { (for example ge- } \\
\text { ometry imagi- } \\
\text { nation) }\end{array}$ & $\begin{array}{l}\text { giving an addi- } \\
\text { tional example } \\
\text { how mathemati- } \\
\text { cal equations } \\
\text { come to life }\end{array}$ & $\begin{array}{lr}\text { making better } \\
\text { conditions } \\
\text { provide own } \\
\text { learning style }\end{array}$ \\
\hline $\begin{array}{l}\text { Competencies } \\
\text { in Science }\end{array}$ & $\begin{array}{l}\text { supporting of ab- } \\
\text { stract concepts } \\
\text { learning; improv- } \\
\text { ing links between } \\
\text { nature objects and }\end{array}$ & $\begin{array}{l}\text { making possible } \\
\text { to operate with } \\
\text { objects, which } \\
\text { are inaccessible }\end{array}$ & $\begin{array}{l}\text { demonstrating } \\
\text { variety of sci- } \\
\text { ence implemen- } \\
\text { tation; motivat- } \\
\text { ing for science }\end{array}$ & $\begin{array}{lr}\text { making better } \\
\text { conditions to } \\
\text { provide own } \\
\text { learning style }\end{array}$ \\
\hline
\end{tabular}




\begin{tabular}{|c|c|c|c|c|}
\hline \multirow[b]{2}{*}{ Competency } & \multicolumn{4}{|c|}{ Component of Competency } \\
\hline & Cognitive & $\begin{array}{c}\text { Skills and } \\
\text { Experience }\end{array}$ & Values & $\begin{array}{l}\text { Social and } \\
\text { Behavioral }\end{array}$ \\
\hline & $\begin{array}{l}\text { phenomena (in- } \\
\text { cluding inaccessi- } \\
\text { ble for direct cog- } \\
\text { nition) }\end{array}$ & $\begin{array}{l}\text { for direct cogni- } \\
\text { tion }\end{array}$ & $\begin{array}{l}\text { learning due to } \\
\text { making abstract } \\
\text { concepts not ab- } \\
\text { stract ones }\end{array}$ & \\
\hline $\begin{array}{l}\text { Digital } \\
\text { Competency }\end{array}$ & $\begin{array}{l}\text { widening } \text { outlook; } \\
\text { getting } \\
\text { ledge about AR }\end{array}$ & $\begin{array}{l}\text { acquiring skills } \\
\text { and getting ex- } \\
\text { perience in mas- } \\
\text { tering subjec- } \\
\text { tively new tech- } \\
\text { nologies }\end{array}$ & $\begin{array}{l}\text { demonstrating } \\
\text { the importance } \\
\text { of digital liter- } \\
\text { acy in the mod- } \\
\text { ern world }\end{array}$ & $\begin{array}{l}\text { mastering new } \\
\text { ways of digital } \\
\text { communication } \\
\text { (including learn- } \\
\text { ing one) }\end{array}$ \\
\hline $\begin{array}{l}\text { Lifelong } \\
\text { Learning }\end{array}$ & $\begin{array}{l}\text { demonstrating in- } \\
\text { finite technologi- } \\
\text { cal progress }\end{array}$ & $\begin{array}{l}\text { getting new } \\
\text { learning habits }\end{array}$ & $\begin{array}{l}\text { demonstrating } \\
\text { both entertain- } \\
\text { ing and useful } \\
\text { learning poten- } \\
\text { tial }\end{array}$ & $\begin{array}{l}\text { mastering new } \\
\text { ways of learning } \\
\text { communication } \\
\text { and self-devel- } \\
\text { opment }\end{array}$ \\
\hline \begin{tabular}{|l|} 
Sense of Initia- \\
tive and Entre- \\
preneurship
\end{tabular} & $\begin{array}{l}\text { gaining knowled- } \\
\text { ge about effective } \\
\text { ways of organiz- } \\
\text { ing information } \\
\text { and developing } \\
\text { flexible thinking }\end{array}$ & $\begin{array}{l}\text { acquiring skills } \\
\text { and getting ex- } \\
\text { perience of ap- } \\
\text { plying the same } \\
\text { technology in } \\
\text { different fields }\end{array}$ & \begin{tabular}{|l} 
giving an op- \\
portunity to \\
adapt to con- \\
stantly chang- \\
ing situations \\
(using an exam- \\
ple of AR)
\end{tabular} & $\begin{array}{l}\text { mastering new } \\
\text { effective ways of } \\
\text { communication }\end{array}$ \\
\hline $\begin{array}{l}\text { Cultural } \\
\text { Awareness }\end{array}$ & $\begin{array}{l}\text { mastering new ef- } \\
\text { fective ways of } \\
\text { gaining cultural } \\
\text { knowledge }\end{array}$ & \begin{tabular}{|l} 
improving \\
praxeological \\
component of \\
technical aware- \\
ness as a neces- \\
sary part of per- \\
sonal cultural \\
awareness
\end{tabular} & $\begin{array}{l}\text { helping to un- } \\
\text { derstand the im- } \\
\text { portance of cul- } \\
\text { tural awareness } \\
\text { by making } \\
\text { cross-cultural } \\
\text { links more ob- } \\
\text { vious }\end{array}$ & $\begin{array}{l}\text { giving more op- } \\
\text { portunities for } \\
\text { creating own } \\
\text { style of self-de- } \\
\text { velopment }\end{array}$ \\
\hline \begin{tabular}{|lr|}
\multicolumn{2}{|l|}{ Cological } \\
Competencies \\
and & Health \\
Care &
\end{tabular} & $\begin{array}{lr}\text { making better } \\
\text { conditions for un- } \\
\text { derstanding } \\
\text { complexity } \\
\text { ecological } \\
\text { medicine } \\
\text { cesses }\end{array}$ & $\begin{array}{l}\text { acquiring skills } \\
\text { and getting ex- } \\
\text { perience of } \\
\text { health care by } \\
\text { themselves (us- } \\
\text { ing sport facili- } \\
\text { ties with AR) }\end{array}$ & $\begin{array}{l}\text { demonstrating } \\
\text { the importance } \\
\text { of health care } \\
\text { and saving the } \\
\text { environment } \\
\text { due to under- } \\
\text { standing links } \\
\text { between nature } \\
\text { phenomena and } \\
\text { human activi- } \\
\text { ties }\end{array}$ & $\begin{array}{lr}\text { making better } \\
\text { conditions to } \\
\text { create own } \\
\text { health care pro- } \\
\text { gramme using } \\
\text { sport facilities } \\
\text { with AR }\end{array}$ \\
\hline
\end{tabular}

The most essential drawbacks of using AR are connected with deficient studies of its influence on users' health and a lack of privacy and security [15]. We should say that 
the last problem is mainly caused by irresponsible using of AR; it is not AR itself. That is why it is especially important to teach students basics of AR using (including safety regulations). One of the difficulties, which we face applying AR at Ukrainian secondary school, is their English interface. We can overcome this drawback by developing foreign language competency.

\section{CLIL Approach In Education}

\subsection{CLIL Definition}

English teaching is still based on traditional education with textbooks as a main resource. The textbooks are mainly focused on grammar material and stereotypical cultural views. This way of teaching does not encourage students to learn language. New methods and approaches should be used to motivate students and to adapt to their learning needs and styles. Content and Language Integrated Learning (CLIL) is considered to be one of such approaches [9]. CLIL is a dual-focused educational approach in which an additional language is used for the learning and teaching of content and language with the objective of promoting both content and language mastery to pre-defined levels $[9$, pp. 2, 65].

\subsection{Risks and Benefits of CLIL Approach}

According to Do Coyle, Bernardette Holmes, and Lid King there are four dimensions (4 Cs) which form a conceptual CLIL framework: content, cognition, communication and culture [4]. The authors define five key characteristics which have been drawn from experience of working with successful CLIL.

1. Choosing appropriate content

- CLIL is about new learning. In a CLIL lesson the learner is discovering new knowledge, developing new or existing skills and deepening understanding;

- lessons must integrate subject area content and language content;

- content planning involves choosing relevant contexts for learning which are appropriate to the learners' age, ability and interests and provide meaningful interaction with and through the language.

2. Developing intercultural understanding

- CLIL actively seeks to promote intercultural understanding by planning and providing rich opportunities to investigate and reflect on different cultures, traditions and values;

- This approach not only involves learning content through another language, but also often involves learning content through another cultural lens.

3. Using language to learn/learning to use language 
- CLIL involves rich input. Learners are expected to interact with language which is accessible to their existing linguistic level but which promotes linguistic progression;

- learning new content through language often requires learners to find information from spoken and written text which is at a higher level than the learners' current productive capability;

- CLIL accelerates the development of language learning strategies to support learners in working out the meaning of what they hear and read and using prior knowledge to predict content.

4. Making meanings that matter

- There is an expectation that CLIL will involve interaction in the target language within and beyond the classroom;

- learners will have opportunities to use language for authentic communication;

- CLIL provides motivating contexts for communication which encourage students to use language to express thoughts, ideas and feelings which matter to them.

5. Progression

- In a sequence of learning there will be evidence of scaffolding in both language using and interaction with content;

- learners will progress in language and in the content subject;

- learners will develop higher order thinking skills, demonstrating their ability to make observations, analyze, generalize and apply their skills to fresh contexts.

CLIL develops a positive attitude to learning by means of diverse educational activities. For instance, students get more language practice including not only dependent on classical language based activities (speaking, reading, writing, listening), but doing experiments, solving problems, dealing with laboratory assignments etc. This can increase students' motivation to learn and can enable them to progress more quickly. CLIL approach allows to be more flexible and employable at the labour market, provides learning mobility and helps to adapt more quickly to constant changes in our increasingly interconnected world. At CLIL lessons students are aware that knowledge and skills are applicable to a wide range of fields. They gain a healthy appreciation of skills and become more motivated to improve them.

CLIL approach involves cooperation and mutual assistance. It provides collaborative environment for both language and science subject learning in a practical way. Students are helpful in assisting each other when getting either into language or science problems. Such situation promotes partnership and cooperation. Advantages of CLIL approach (in regard to key competencies [7]) are reflected in the table 3.

The implementation of CLIL approach in secondary school educational process allows us to distinguish such backgrounds of CLIL lessons as:

- proper level of students' language skills;

- parents' and students' demands for social mobility;

- the teachers' readiness to introduce CLIL lessons; 
- social competency of all educational process participants.

Table 3. Advantages of CLIL science lessons approach in key competencies forming

\begin{tabular}{|c|c|c|c|c|}
\hline \multirow[b]{2}{*}{$\begin{array}{l}\text { Compe- } \\
\text { tency }\end{array}$} & \multicolumn{4}{|c|}{ Component of Competency } \\
\hline & Cognitive & $\begin{array}{c}\text { Skills and } \\
\text { Experience }\end{array}$ & Values & $\begin{array}{l}\text { Social and } \\
\text { Behavioral }\end{array}$ \\
\hline $\begin{array}{l}\text { Foreign } \\
\text { Language } \\
\text { Compe- } \\
\text { tency }\end{array}$ & $\begin{array}{l}\text { widening cross- } \\
\text { subject vocabula- } \\
\text { ry }\end{array}$ & $\begin{array}{lr}\text { creating } & \text { real le- } \\
\text { arning r } & \text { situa- } \\
\text { tions; providing } \\
\text { more language } \\
\text { practice }\end{array}$ & $\begin{array}{l}\text { realizing the neces- } \\
\text { sity of languages to } \\
\text { access science so- } \\
\text { urces; using lan- } \\
\text { guages for real } \\
\text { practical purposes }\end{array}$ & $\begin{array}{l}\text { providing mutual } \\
\text { assistance in lear- } \\
\text { ning languages; } \\
\text { making the social } \\
\text { environment more } \\
\text { accessible }\end{array}$ \\
\hline $\begin{array}{l}\text { Mathemat- } \\
\text { ical Com- } \\
\text { petency }\end{array}$ & $\begin{array}{l}\text { learning specific } \\
\text { terms in a foreign } \\
\text { language }\end{array}$ & $\begin{array}{l}\text { learning culture- } \\
\text { based math } \\
\text { rules (e.g. mne- } \\
\text { monics) }\end{array}$ & $\begin{array}{l}\text { realizing an impor- } \\
\text { tance of studying } \\
\text { math for learning } \\
\text { mobility }\end{array}$ & $\begin{array}{l}\text { empowering soci- } \\
\text { al interaction in } \\
\text { learning math }\end{array}$ \\
\hline $\begin{array}{l}\text { Compe- } \\
\text { tencies in } \\
\text { Science }\end{array}$ & $\begin{array}{l}\text { learning terms in } \\
\text { a foreign lan- } \\
\text { guage; providing } \\
\text { a wider variety of } \\
\text { learning objects } \\
\text { and original sci- } \\
\text { entific sources }\end{array}$ & $\begin{array}{l}\text { learning culture- } \\
\text { based } \\
\text { rules (e. g. mne- } \\
\text { monics) }\end{array}$ & $\begin{array}{l}\text { understanding the } \\
\text { importance of stud- } \\
\text { ying science for } \\
\text { learning mobility }\end{array}$ & $\begin{array}{l}\text { empc } \\
\text { al in } \\
\text { learn }\end{array}$ \\
\hline $\begin{array}{l}\text { Lifelong } \\
\text { Learning }\end{array}$ & $\begin{array}{l}\text { giving opportuni- } \\
\text { ties to work with } \\
\text { various learning } \\
\text { resources; } \\
\text { providing cross- } \\
\text { subject links }\end{array}$ & $\begin{array}{l}\text { acquiring } \\
\text { of skills } \\
\text { knowledge in } \\
\text { different } \\
\text { guages }\end{array}$ & $\begin{array}{l}\text { increasing aware- } \\
\text { ness of developing } \\
\text { in different fields; } \\
\text { presenting teach- } \\
\text { ers' examples of } \\
\text { development in } \\
\text { various spheres }\end{array}$ & $\begin{array}{l}\text { forming collabo- } \\
\text { ration habits due } \\
\text { to mutual assis- } \\
\text { tance in learning } \\
\text { both language and } \\
\text { science }\end{array}$ \\
\hline $\begin{array}{l}\text { Social and } \\
\text { Civic } \\
\text { Compe- } \\
\text { tencies }\end{array}$ & $\begin{array}{l}\text { developing better } \\
\text { cross-cultural un- } \\
\text { derstanding }\end{array}$ & $\begin{array}{l}\text { shaping toleran- } \\
\text { ce and respect to } \\
\text { other cultures; } \\
\text { increasing val- } \\
\text { ues of cultural } \\
\text { peculiarities }\end{array}$ & $\begin{array}{l}\text { demonstrating dif- } \\
\text { ferent cultures im- } \\
\text { pact on science }\end{array}$ & $\begin{array}{l}\text { appreciating plu- } \\
\text { ralism; broaden- } \\
\text { ing social experi- } \\
\text { ence }\end{array}$ \\
\hline $\begin{array}{l}\text { Sense of } \\
\text { Initiative } \\
\text { and Entre- } \\
\text { preneur- } \\
\text { ship }\end{array}$ & $\begin{array}{l}\text { providing a wider } \\
\text { range of re- } \\
\text { sources }\end{array}$ & $\begin{array}{l}\text { broadening te- } \\
\text { amwork experi- } \\
\text { ence (including } \\
\text { leadership qual- } \\
\text { ities) }\end{array}$ & $\begin{array}{l}\text { demonstrating im- } \\
\text { portance of per- } \\
\text { sonal input in com- } \\
\text { mon success }\end{array}$ & $\begin{array}{l}\text { providing mutual } \\
\text { assistance while } \\
\text { learning both lan- } \\
\text { guage and science }\end{array}$ \\
\hline $\begin{array}{l}\text { Cultural } \\
\text { Awareness }\end{array}$ & widening outlook & $\begin{array}{l}\text { widening a ran- } \\
\text { ge of multilin- } \\
\text { guistic activities }\end{array}$ & $\begin{array}{l}\text { recognizing the im- } \\
\text { portance of differ- } \\
\text { ent knowledge } \\
\text { spheres }\end{array}$ & $\begin{array}{l}\text { raising cultural } \\
\text { awareness; enhan- } \\
\text { cing ability for } \\
\text { cultural reflection }\end{array}$ \\
\hline
\end{tabular}


While introducing CLIL lessons we face such difficulties as:

- curriculum coordination;

- consuming a lot of time to prepare a CLIL lesson;

- a lack of appropriate materials and resources.

Despite all challenges and problems, CLIL approach has its advantages. Taking into consideration both recent researches [4;9] and our practical experience we can conclude that CLIL lessons:

- are more interesting and motivating;

- are time-saving (both subjects are learnt together);

- help students to feel confident;

- promote communication and understanding;

- contribute to personal and cultural development;

- provide educational diversity;

- increase mobility.

\section{Conclusions}

To conclude, nowadays both new learning and IC technologies are required to satisfy "Zeds" demands. For instance, all reviewed technologies provide individual learning strategies: AR and cloud-based learning environment help students to work according to their personal style, CLIL approach helps students to feel confident either in language or non-language subjects. Cloud-based learning environment gives students and teachers great opportunities for communication and cooperation via online tools, and CLIL approach is based on their teamwork and collaboration.

Although AR and CLIL are supposed to be relatively new technologies, in fact, they are sufficiently mature and can be used at school. The using of both AR and CLIL in cloud-based science learning environment helps to form and develop 9 of 10 key competencies (except native language competency). Cloud-based technologies provide online and offline access to learning materials and give more opportunities for individual and group work. Augmented reality helps to create the firm links between real and virtual objects. Moreover, it is very beneficial for studying abstract mathematical and science concepts. Content and language integrated learning creates conditions for efficient group and individual work in language and science learning.

We should mention that implementation of these technologies is reasonable only under certain conditions. AR using requires gadgets and appropriate level of teachers' digital literacy. Conversely, CLIL implies the proper level of foreign language competency and readiness of all participants of education process to introduce this approach. The main difficulties, we face applying these technologies in science learning, are connected with organization of educational process not with teaching or learning. To sum up, cloud-based, AR and CLIL technologies together create rich learning and teaching environment for effective and interesting education of modern students. 


\section{References}

1. Barnes \& Noble College: Getting to Know Gen Z - Exploring Middle and High Schoolers' Expectations for Higher Education. https://next.bncollege.com/wp-content/uploads/2015/10/Gen-Z-Research-Report-Final.pdf (2015). Accessed 15 Jan 2018

2. Billinghurst, M., Duenser, A.: Augmented Reality in the Classroom. Computer. 45(7), 5663 (2012). doi:10.1109/MC.2012.111

3. Cieutat, J.-M., Hugues, O., Ghouaiel, N.: Active Learning based on the use of Augmented Reality Outline of Possible Applications: Serious Games, Scientific Experiments, Confronting Studies with Creation, Training for Carrying out Technical Skills. International Journal of Computer Applications. 46(20), 31-36 (2012).

4. Coyle, D., Holmes, B., King, L.: Towards an Integrated Curriculum - CLIL National Statement and Guidelines. The Languages Company. http://www.rachelhawkes.com/PandT/CLIL/CLILnationalstatementandguidelines.pdf (2009). Accessed 15 Jan 2018

5. Diegmann P., Schmidt-Kraepelin M., Van den Eynden S., Basten D.: Benefits of Augmented Reality in Educational Environments - A Systematic Literature Review. In: Thomas, O., Teuteberg, F. (eds.) Proceedings the $12^{\text {th }}$ International Conference on Wirtschaftsinformatik, Osnabrück, 4-6 March 2015, pp. 1542-1556. http://aisel.aisnet.org/wi2015/103/ (2015). Accessed 10 Jan 2018

6. Exploring augmented reality : hearing before the Committee on Commerce, Science, and Transportation, United States Senate, One Hundred Fourteenth Congress, second session, November 16, 2016. U.S. Government Publishing Office, Washington (2017).

7. Kabinet Ministriv Ukrainy: Derzhavnyi standart bazovoi i povnoi zahalnoi serednoi osvity (The State Standard of the Basic and Complete Secondary Education). Zakonodavstvo Ukrainy. http://zakon3.rada.gov.ua/laws/show/1392-2011-\%D0\%BF (2011). Accessed 25 Dec 2017

8. Kislova, M.A., Semerikov, S.O., Slovak, K.I.: Rozvytok mobilnoho navchalnoho seredovyshcha yak problema teorii i metodyky vykorystannia informatsiino-komunikatsiinykh tekhnolohii v osviti (Development of mobile learning environment as a problem of the theory and methods of use of information and communication technologies in education). Information Technologies and Learning Tools. 42(4), 1-19 (2014)

9. Marsh, D.: CLIL/EMILE - the European dimension: actions, trends and foresight potential. University of Jyväskylä, Jyväskylä (2002)

10. Merzlykin, O.V., Merzlykin, P.V.: Zasoby informatsiino-komunikatsiinykh tekhnolohii pidtrymky navchalnykh doslidzhen u profilnomu navchanni fizyky (The tools of information and communication technologies for learning researches support in profile physics learning). Information Technologies and Learning Tools. 48(4), 58-87 (2015)

11. Merzlykin, O.V., Semerikov, S.O.: Perspektyvni khmarni tekhnolohii v osviti (Prospective Cloud Technologies in Education). In: Proceedings of the scientific and practical workshop on Cloud Technologies in Modern University, Cherkasy, 24 Mar 2015, pp. 31-33. ChDTU, Cherkasy (2015)

12. Merzlykin, O.V.: Khmarni tekhnolohii yak zasib formuvannia doslidnytskykh kompetentnostei starshoklasnykiv u protsesi profilnoho navchannia fizyky (Cloud technologies as tools of high school students' research competencies forming in profile physics learning). Thesis for the degree of candidate of pedagogical science, Institute of Information Technologies and Learning Tools of the NAPS of Ukraine (2017)

13. Merzlykin, O.V.: Mozhlyvosti vykorystannia Google Classroom dlia realizatsii khmarnoho seredovyshcha pidtrymky navchalnykh doslidzhen z fizyky (The possibilities of using 
Google Classroom for implementing cloud environment of support physics learning researches). In: Proceeding of the $2^{\text {nd }}$ Ukrainian scientific and practical conference of young scientists "Scientific Youth-2014", pp. 110-112. Institute of Information Technologies and Learning Tools of the NAES of Ukraine, Kyiv (2014)

14. Modlo, E.O., Echkalo, Yu.V., Semerikov, S.O., Tkachuk, V.V.: Vykorystannia tekhnolohii dopovnenoi realnosti u mobilno oriientovanomu seredovyshchi navchannia VNZ (Using technology of augmented reality in a mobile-based learning environment of the higher educational institution). Naukovi zapysky, Seriia: Problemy metodyky fizyko-matematychnoi i tekhnolohichnoi osvity. 11(1), 93-100 (2017)

15. Roesner, F., Kohno, T., Molnar, D.: Security and Privacy for Augmented Reality Systems. Communications of The ACM. 57(4), 88-96 (2014). doi:10.1145/2580723.2580730

16. Rosenberg, L.B.: The Use of Virtual Fixtures As Perceptual Overlays to Enhance Operator Performance in Remote Environments: Interim Report for The Period June 1992 to July 1992. Wright-Patterson Air Force Base, Ohio (1992)

17. Semerikov, S.O., Striuk, A.M., Slovak, K.I., Rashevska, N.V., Yechkalo, Yu.V.: Liudyna z kompiuternym oblychchiam (do 80-richchia Aivena Edvarda Sazerlenda) (A man with a computer face (to the 80th anniversary of Ivan Edward Sutherland)). New computer technology. 16, 9-24 (2018)

18. Sutherland, I.E.: The Ultimate Display. In: Proceedings of the IFIP Congress 1965. New York City, 24-29 May 1965, vol. 2, pp. 506-508. Macmillan and Co., London (1965)

19. Technology Research \& Insight for IT Professionals | Gartner Inc. https://www.gartner.com/technology/it_professionals.jsp (2018). Accessed 26 Jan 2018

20. Teplytskyi, I.O., Semerikov, S.O., Polishchuk, O.P.: Model mobilnoho navchannia v serednii ta vyshchii shkoli (The model of mobile learning in middle and high school). In: Proceedings of the $3^{\text {rd }}$ Ukrainian scientific and methodical workshop on Computer Simulation in Education, Kryvyi Rih, 24 Apr 2008, pp. 45-46. KDPU, Kryvyi Rih (2008) 